\title{
KELELAHAN EMOSIONAL TERHADAP MOTIVASI KERJA PEGAWAI PADA PT PLN PERSERO WILAYAH MALUKU DAN MALUKU UTARA
}

\author{
Imelda Talahatu*
}

Jurusan Administrasi Bisnis, Politeknik Negeri Ambon:

\begin{abstract}
ABSTRAK: Penelitian ini bertujuan untuk menganalisis pengaruh kelelahan emosional terhadap motivasi kerja dan kepuasan kerja pegawai pada PT PLN (Persero) Wilayah Maluku dan Maluku Utara. Data penelitian ini dikumpul menggunakan kuesioner yang dibagikan kepada 52 orang responden, dan dianalisis secara deskriptif serta analisa jalur. Hasilnya menunjukan kelelahan emosional berpengaruh secara negatif dan signifikan terhadap motivasi kerja dan kepuasan kerja pegawai PT PLN (Persero) Wilayah Maluku dan Maluku Utara. Demikian pula motivasi kerja berpengaruh positif dan signifikan terhadap kepuasan kerja pegawai PT PLN (Persero) Wilayah Maluku dan Maluku Utara. Hasil analisis deskriptif menunjukan para pegawai cukup mengalami kelelahan emosional, namun motivasi kerja dan kepuasan kerja mereka tetap terjaga.
\end{abstract}

Kata kunci : Kelelahan Emosional, Motivasi Kerja, Kepuasan Kerja

\begin{abstract}
This study aims to analyze the influence of burnout on work motivation and employee's job satisfaction at PT PLN (Persero) Maluku and North Maluku. The data of this study were collected using questionnaires distributed to 52 respondents, analyzed descriptively and by path analysis. The result shows that burnout has a negative and significant effect on work motivation and job satisfaction of employees of PT PLN (Persero) Maluku and North Maluku. Similarly, the motivation of work has a positive and significant effect on job satisfaction of employees of PT PLN (Persero) Maluku and North Maluku. Descriptive analysis results show that employees suffer from burnout, but their motivation and job satisfaction are maintained.
\end{abstract}

Keywords: Burnout, Work Motivation, Work satisfaction

\footnotetext{
* Surel Korespondensi Penulis: imelda.talahatu@polnam.ac.id

DOI: $10.24252 /$ minds.v5i2.6233
} 


\section{PENDAHULUAN}

Setiap organisasi baik itu swasta maupun pemerintah akan berupaya dan berorientasi pada berkembangnya organisasi yang diindikasikan dengan adanya peningkatan pendapatan, yang sejalan pula dengan adanya peningkatan kesejahteraan pegawainya. Untuk mencapai tujuan tersebut organisasi sering menghadapi kendala, di antaranya adalah ketidakpuasan kerja dari pegawainya. Indikator kepuasan atau ketidakpuasan kerja pegawai dapat diperlihatkan oleh beberapa aspek (Simamora, 2007) di antaranya jumlah kehadiran atau jumlah kemangkiran, perasaan senang atau tidak senang dalam melaksanakan pekerjaan, perasaan adil atau tidak adil dalam menerima imbalan, suka atau tidak suka dengan jabatan yang dipegangnya, sikap menolak pekerjaan atau menerima dengan penuh tanggung jawab, tingkat motivasi para pegawai yang tercermin dalam perilaku pekerjaan, reaksi positif atau negatif terhadap kebijakan organisasi, dan unjuk rasa atau perilaku destruktif lainnya.

Karyawan yang puas membawa pengaruh yang positif bagi organisasi seperti meningkatnya efisiensi dan produktivitas. Sebaliknya, karyawan yang tidak puas mungkin mengakibatkan turnover dan kemangkiran yang tinggi (Luthans, 2006). Berkenaan dengan kepuasan kerja karyawan, sebenarnya banyak faktor yang memengaruhi ketidakpuasan pegawai dalam pekerjaannya. Kepuasan kerja merupakan minat utama dalam bidang perilaku organisasi dan praktek manajemen sumber daya manusia, karena itu secara umum dalam bidang perilaku organisasi kepuasan kerja adalah sikap yang paling penting dan sering dipelajari (Luthans, 2006).

Tuntutan kerja yang terlalu banyak yang dikenakan dalam waktu yang singkat menyebabkan seseorang mengalami tekanan emosi dan keterpisahan secara emosi. Kondisi tersebut pada akhirnya akan menyebabkan terjadinya kelelahan emosional atau burnout (Rahman et.al, 2014).

Kelelahan emosional bukan suatu gejala dari tekanan kerja, tetapi merupakan hasil dari tekanan kerja yang tidak dapat dikendalikan dan merupakan suatu keadaan yang serius (Stanley, 2004). Jadi, kelelahan emosional merupakan suatu respon terhadap keadaan kerja yang menekan. Penelitian menunjukkan bahwa pekerja human service mengalami kelelahan emosional dalam merespon terhadap tekanan kerja (Berry, 1998). Sementara itu, berdasarkan perspektif teori belajar (learning theory), kelelahan emosional merupakan hasil dari pengharapan yang salah terhadap imbalan, hasil, dan kesuksesan (Schaufeli dan Buunk, 1996). Dalam hal ini, pekerja meletakkan standar keberhasilan pribadi yang terlalu tinggi yang sukar dicapai berdasarkan kemampuan yang dimilikinya.

Keletihan emosional merujuk kepada keadaan keletihan dari segi emosi dan perasaan. Keletihan ini membawa kepada kemerosotan prestasi individu berbanding usaha yang telah dilakukan sebelumnya. Individu merasa dirinya kurang bertenaga dan memerlukan waktu yang lebih panjang untuk beristirahat. Pekerja yang mengalami keletihan emosi yang berkepanjangan 
berdampak pada kepuasan kerja dan rendahnya kualitas pencapaian kerja (Motowildo, 1986). Prosser et al (1999) mengatakan kelelahan emosional menyebabkan tekanan dan rendahnya kepuasan kerja. Tekanan kerja yang berhubungan dengan klien menyebabkan pekerja mengalami depersonalisasi. Pekerja cenderung bersikap negatif, menjaga jarak dan tidak perduli terhadap orang-orang yang ada dilingkungan kerjanya. Selain itu, rendahnya hasrat pencapaian pretasi diri juga ditandai dengan adanya perasaan tidak puas terhadap diri sendiri, pekerjaan dan kehidupan. Apabila keadaan ini berkelanjutan dan pekerja tidak mendapatkan perhatian dari pihak manajemen akan menyebabkan pekerja menarik diri dan akhirnya mengundurkan diri dari organisasi (Piko, 2006).

Individu yang mengalami gejala kelelahan emosional diidentifikasikan oleh Freudenberg dan Richelson, seperti: 1) Kelelahan yang disertai keletihan. Individu sulit menerima kondisi ini karena mereka selama ini tidak pernah merasa lelah walaupun aktivitas yang dilakukan sangat padat; 2) Lari dari kenyataan. Ini merupakan alat yang digunakan oleh individu untuk menangkal penderitaan yang dialami. Pada saat individu merasa kecewa melihat kenyataan yang tidak sesuai dengan harapan, mereka menjadi tidak perduli terhadap permasalahan yang dihadapi; 3) Kebosanan dan sinisme. Mereka mulai mempertanyakan makna kegiatan yang dilakukan dan mulai merasa bosan dengan kegiatan tersebut; 4) Tidak sabaran dan mudah tersinggung. Hal ini terjadi karena selama ini individu dapat melakukan segala hal dengan cepat. Ketika mengalami kelelahan, kemampuan mereka dalam menyelesaikan sesuatu hal mulai berkurang, sehingga mereka menjadi tidak sabaran dan mudah tersinggung; 5) Merasa tidak dihargai. Usaha yang semakin keras namun tidak disertai dengan energi yang cukup, serta hasil yang diperoleh tidak memuaskan, menyebabkan mereka merasa tidak dihargai oleh orang lain; 6) Keluhan psikosomatis. Individu cenderung mengeluh sakit kepala, ketegangan otot punggung dan gangguan fisik lainnya; 7) Penyangkalan terhadap kegagalan yang dialami dan penyangkalan terhadap ketakutan yang dirasakannya (Amelia dan Zulkarnain, 2005).

Motivasi kerja pegawai merupakan kemauan kerja pegawai yang timbul karena adanya dorongan dari pribadi pegawai yang bersangkutan sebagai hasil integrasi keseluruhan daripada kebutuhan pribadi, pengaruh lingkungan fisik dan pengaruh lingkungan sosial di mana kekuatannya tergantung daripada proses pengintegrasian tersebut (Anoraga, 1992). Motivasi kerja adalah sesuatu yang menimbulkan dorongan atau semangat kerja (Martoyo, 2000), dan kuat lemahnya motivasi kerja seseorang pegawai akan menentukan pula besar kecil prestasinya (As'ad, 2003). Menurut Robbins (1996) motivasi merupakan kesediaan pegawai untuk mengeluarkan tingkat upaya yang tinggi untuk tujuan organisasi, yang dikondisikan oleh kemampuan upaya itu untuk memenuhi beberapa kebutuhan individual. Motivasi kerja merupakan faktorfaktor pendorong yang berada dalam diri individu yang menyebabkan seseorang berperilaku tertentu (Stanford dalam Mangkunegara, 2001). Oleh 
karena itu dengan motivasi yang dimiliki seseorang akan terdorong untuk melakukan tugas pekerjaannya. Seberapa besar hasil pekerjaan turut ditentukan oleh motivasi yang dimiliki oleh pegawai. Semakin besar atau kuat motivasi yang dimiliki, pegawai akan lebih terdorong untuk melaksanakan pekerjaannya.

Sejumlah hasil penelitian menunjukan adanya pengaruh kelelahan emosional terhadap motivasi kerja. Hasil penelitian Koltunovych (2013) menunjukan kelelahan emosional memiliki pengaruh yang negatif terhadap motivasi kerja, demikian pula sebaliknya. Hasil ini menunjukan pegawai yang mengalami kelelahan emosional akan menurunkan motivasi kerjanya. Selain itu, hasil penelitian juga menunjukan adanya pengaruh kelelahan emosional dan motivasi kerja terhadap kepuasan kerja karyawan (Maslach, 1993; Gibson et al., 1996; Igalens dan Roussel, 1999; Low et al., 2001; Zagladi, 2004; Prosser et al., 1999).

Dari uraian di atas, masalah yang akan dibahas dalam penelitian ini adalah apakah kelelahan emosional berpengaruh terhadap motivasi kerja dan kepuasan kerja pegawai PT PLN (Persero) Wilayah Maluku dan Maluku Utara baik secara langsung mapun tidak.

\section{TINJAUAN TEORITIS}

\section{Kelelahan Emosional}

Kelelahan emosional adalah suatu bentuk kelelahan yang disebabkan seseorang bekerja terlalu intens, berdedikasi dan berkomitmen, bekerja terlalu banyak dan terlalu lama serta memandang kebutuhan dan keinginan mereka sebagai hal kedua. Hal tersebut menyebabkan mereka merasakan adanya tekanan-tekanan untuk memberi lebih banyak. Tekanan ini bisa berasal dari dalam diri mereka sendiri, dari klien yang amat membutuhkan, dan dari kepungan para administrator (penilik/pengawas dan sebagainya). Adanya tekanan ini maka timbul rasa bersalah, yang pada gilirannya mendorong mereka untuk menambah energi dengan lebih besar. Ketika realitas yang ada tidak mendukung idealisme mereka, maka mereka tetap berupaya mencapai idealisme tersebut sampai akhirnya sumber diri mereka terkuras, sehingga mereka mengalami kelelahan atau frustrasi yang disebabkan terhalangnya pencapaian harapan (Freudenberger dalam Farber, 1991)

Pekerjaan yang berorientasi melayani orang lain dapat membentuk hubungan yang bersifat asimetris antara pemberi dan penerima pelayanan. Orang yang bekerja pada bidang pelayanan, akan memberikan perhatian, pelayanan, bantuan, dan dukungan kepada klien. Hubungan yang tidak seimbang tersebut dapat menimbulkan ketegangan emosional yang berujung dengan terkurasnya sumber-sumber emosional.

Kelelahan emosional merupakan kondisi emosional di mana seseorang merasa lelah dan jenuh secara mental ataupun fisik sebagai akibat tuntutan pekerjaan yang meningkat. Timbulnya kelelahan ini karena mereka bekerja keras, merasa bersalah, merasa tidak berdaya, merasa tidak ada harapan, 
merasa terjebak, kesedihan yang mendalam, merasa malu, dan secara terus menerus membentuk lingkaran dan menghasilkan perasaan lelah dan tidak nyaman, yang pada gilirannya meningkatkan rasa kesal, dan lingkaran terus berlanjut sehingga dapat menimbulkan kelelahan fisik, kelelahan mental dan keletihan emosional (Pines dan Aronson, 1989).

Kelelahan emosional terjadi akibat perubahan kondisi psikologis pemberi layanan sebagai akibat reaksi terhadap situasi kerja yang tidak menguntungkan berupa umpan balik yang negatif yang diterima seorang pekerja. Hal ini disebabkan karena tuntutan sosial masyarakat sekitar yang menganggap bahwa pekerja pelayanan sosial sudah seharusnya bersikap seperti itu. Demikian juga halnya jika pemberi pelayanan dapat memenuhi standar tersebut, masyarakat pada umumnya tidak memberi pujian.

Maslach dan Jackson (1986) menyatakan kelelahan emosional merupakan sindrom psikologis yang terdiri atas tiga dimensi yaitu keletihan emosional, depersonalisasi, dan low personal accomplishment. Cherniss (1980) mengatakan kelelahan emosional merupakan perubahan sikap dan perilaku dalam bentuk reaksi menarik diri secara psikologis dari pekerjaan, seperti menjaga jarak dengan klien maupun bersikap sinis dengan mereka, membolos, sering terlambat, dan keinginan pindah kerja yang kuat. Pandangan Cherniss ini nampak sejalan dengan pandangan Freuddenberger (Greenberg dan Baron, 1993) bahwa seseorang memiliki sikap antusias dan tujuan yang hendak mereka capai pada awal bekerja. Ia merasa terpanggil untuk bekerja, sehingga idealisme mereka pun tinggi. Namun, stres yang dialami secara kronis menyebabkan mereka mengalami perubahan motivasi, mereka mengalami kelelahan emosional.

\section{Motivasi Kerja}

Motivasi dapat diartikan sebagai suatu dorongan (daya penggerak) yang terdapat dalam diri seseorang untuk melakukan kegiatan guna memperoleh sesuatu yang diinginkan. Setiap individu dalam hidupnya memerlukan kebutuhan, baik kebutuhan jasmani maupun kebutuhan rohani, Motivasi merupakan masalah kompleks dalam organisasi, karena kebutuhan dan keinginan setiap anggota organisasi berbeda satu dengan yang lainnya. Demikian pula, karena setiap anggota suatu organisasi adalah unik secara biologis maupun psikologis, dan berkembang atas dasar proses belajar yang berbeda pula (Suprihanto, dkk, 2003).

Motivasi didefinisikan oleh Stanford (Mangkunegara, 2001) sebagai suatu kondisi yang menggerakkan manusia ke arah suatu tujuan tertentu. Sedangkan dalam hubungannya dengan lingkungan kerja McCormick (Mangkunegara, 2001) mengemukakan bahwa motivasi kerja didefinisikan sebagai kondisi yang berpengaruh membangkitkan, mengarahkan dan memelihara perilaku yang berhubungan dengan lingkungan kerja.

Worth (Simamora, 2007), menyatakan motivasi adalah kondisi psikologis yang berada dalam diri seseorang yang mendorong untuk 
melakukan sesuatu kegiatan dengan baik, sehingga mencapai tujuan yang diharapkan. Dalam berbagai bidang kehidupan, motivasi mempunyai peranan yang sangat penting. Siagian (2002) berpendapat timbulnya motivasi dapat disebabkan oleh berbagai faktor, seperti adanya kebutuhan akan sesuatu hal, keinginan terhadap sesuatu, ingin tahu, kesenangan dan lain-lain. Motivasi seperti itu disebut motivasi instrinsik, sedangkan motivasi yang berasal dari luar diri seseorang disebut motivasi ekstrinsik.

Suprihanto, dkk (2003) menyebutkan motivasi sebagai usaha secara sadar untuk mengetahui perilaku seseorang agar supaya mengarah tercapainya tujuan organisasi. Sedangkan Kartono (1994) mengemukakan motivasi merupakan alasan dorongan dari seseorang untuk membuat ide pokok yang selalu berpengaruh besar terhadap tingkah laku manusia, maka motivasi tidak hanya berwujud kebutuhan ekonomi saja (bentuk uang) sebabnya antara lain adalah banyaknya orang yang suka hati bekerja terus sekalipun ia tidak memerlukan lagi benda-benda dan material, gangguan dan keamanan sendiri serta keluarganya sudah terjamin, namun seorang dengan ikhlas hati meneruskan pekerjaan.

Peranan dan pentingnya motivasi dijelaskan Manullang (2002) untuk menggiatkan pegawai atau orang-orang, agar mereka bersemangat dan dapat mencapai hasil sebagaimana dikehendaki dari orang-orang tersebut. Manfaat motivasi kerja yang utama adalah menciptakan gairah kerja, sehingga produktivitas kerja meningkat. manfaat yang diperoleh karena bekerja dengan orang-orang yang termotivasi adalah pekerjaan dapat diselesaikan sesuai standar yang benar dan dalam skala waktu yang sudah ditentukan, serta orang senang melakukan pekerjaannya.

Herzberg (Martoyo, 2000) mengembangkan teori hierarki kebutuhan Maslow menjadi teori dua faktor tentang motivasi. Dua faktor itu dinamakan faktor pemuas (motivation factor) yang disebut dengan satisfer atau intrinsic motivation dan faktor pemelihara (maintenance factor) yang disebut dengan disatisfier atau intrinsic motivation. Faktor pemuas disebut juga motivator yang merupakan faktor pendorong seseorang untuk berprestasi yang bersumber dari dalam diri seseorang tersebut (kondisi instrinsik). Orang yang termotivasi antara lain memiliki 1) Prestasi yang diraih (achievement), 2) Pengakuan orang lain (recognition), 3) Tanggung jawab (responsibility), 4) Peluang untuk maiu (advancement) 5) Kepuasan kerja itu sendiri (the work it self), 6) Kemungkinan pengembangan karir (the possibility of career growth). Sedangkan faktor pemelihara (maintenance factor) disebut juga hygiene factor merupakan faktor yang berkaitan dengan pemenuhan kebutuhan untuk memelihara keberadaan pegawai sebagai manusia, pemeliharaan ketentraman dan kesehatan. Faktor ini juga disebut dissafisfier (sumber ketidakpuasan) yang merupakan tempat pemenuhan kebutuhan tingkat rendah yang dikualifikasikan ke dalam faktor ekstrinsik, meliputi (1) kompensasi, (2) keamanan; (3) stress kerja; (4) kondisi kerja; (5) status; dan (6) prosedur perusahaan. 


\section{Kepuasan Kerja}

Davis (1985) mendefinisikan kepuasan kerja sebagai sekumpulan perasaan menyenangkan dan tidak menyenangkan terhadap pekerjaan mereka. Kepuasan kerja dipandang sebagai perasaan senang atau tidak senang yang relatif, yang berbeda dari pemikiran objektif dan keinginan perilaku. Karena perasaan terkait dengan sikap seseorang, maka kepuasan kerja dapat didefinisikan sebagai sikap umum seseorang terhadap pekerjaan dan harapannya pada organisasi tempat ia bekerja. Kepuasan kerja menunjukkan pada sikap emosional positif yang berdasar pada pengalaman kerja seseorang (Locke dalam Luthans, 2006).

Kepuasan kerja merupakan suatu sikap umum seorang individu terhadap pekerjaannya. Seseorang dengan kepuasan kerja tinggi menunjukkan sikap yang positif terhadap kerja itu, seseorang yang tidak puas dengan pekerjaannya menunjukkan sikap yang negatif terhadap pekerjaan itu (Robbins, 2001).

Kepuasan kerja memiliki tiga dimensi. Pertama, kepuasan kerja adalah tanggapan emosional seseorang terhadap situasi kerjanya. Kepuasan ini bersifat abstrak, tidak dapat dilihat hanya dapat diduga. Kedua, kepuasan kerja hanya dapat ditentukan oleh sejauh mana hasil kerja memenuhi atau melebihi harapan seseorang. Ketiga, kepuasan kerja menunjukkan beberapa sikap seseorang yang saling terkait (Luthans, 2006).

Menurut Robins (2001) sumber kepuasan kerja terdiri atas pekerjaan yang menantang, imbalan yang sesuai, kondisi/ lingkungan kerja yang mendukung, dan rekan kerja yang mendukung. Smith, Kendal dan Hulin (Robins, 2001) mengungkapkan kepuasan kerja bersifat multidimensi di mana seseorang merasa lebih atau kurang puas dengan pekerjaannya, supervisornya, tempat kerjanya dan sebagainya. Menurut mereka, terdapat 5 dimensi yang memengaruhi respon afektif seseorang terhadap pekerjaannya, yaitu :

a. Pekerjaan itu sendiri, yaitu sejauh mana pekerjaan menyediakan kesempatan seseorang untuk belajar memperoleh tanggung jawab dalam suatu tugas tertentu dan tantangan untuk pekerjaan yang menarik.

b. Bayaran, yaitu upah yang diperoleh seseorang sebanding dengan usaha yang dilakukan dan sama dengan upah yang diterima oleh orang lain dalam posisi kerja yang sama

c. Kesempatan untuk promosi, yaitu kesempatan seseorang untuk meraih atau dipromosikan ke jenjang yang lebih tinggi dalam organisasi

d. Atasan, yaitu kemampuan atasan untuk memberikan bantuan tehnis dan dukungan terhadap pekerjaan yang menjadi tanggung jawab para bawahan

e. Rekan kerja, yaitu sejauh mana rekan kerja secara tehnis cakap dan secara sosial mendukung tugas rekan kerja lainnya.

Hubungan Kelelahan Emosional dengan Motivasi Kerja dan Kepuasan Kerja Pegawai

Pegawai yang mengalami kelelahan emosional memiliki kecenderungan untuk mendapatkan pencapaian kerja yang rendah. Kelelahan emosional yang 
dialami oleh para pekerja memengaruhi kualitas dan efektfitas pekerjaan, hubungan sosial antar pekerja menjadi renggang, serta menimbulkan adanya perasaan negatif terhadap pekerjaan, tempat kerja dan konsumen yang dilayani. Kelelahan emosional memiliki pengaruh negatif terhadap motivasi kerja, di mana pegawai yang mengalami kelelahan emosional akan memengaruhi motivasi kerjanya. Pegawai yang memiliki motivasi kerja yang rendah cenderung mengalami kelelahan emosional (Tawale, dkk., 2011). Hasil penelitian menunjukan kelelahan emosional memiliki pengaruh yang negatif terhadap motivasi kerja, demikian pula sebaliknya (Koltunovych, 2013). Dengan adannya kelelahan emosional yang dialami para karyawan, akan berpengaruh terhadap pelaksanaan tugas pekerjaan, yang pada gilirannya akan memengaruhi tingkat kepuasan kerja mereka. Hasil penelitian Maslach (1993) menunjukan bahwa kelelahan emosional memiliki pengaruh yang negatif terhadap kepuasan kerja karyawan. Demikian pula hasil penelitian Low et al. (2001), Zagladi (2004), Al-Kahtani dan Allam (2014) serta Syech, et al. (2015). Sedangkan hasil penelitian Gibson et al. (1996), Igalens dan Roussel (1999), serta Jehanzeb et al., (2012) menunjukan bahwa karyawan yang termotivasi cenderung untuk mendapatkan kepuasan dalam bekerja.

Dari uraian di atas, dapat dikembangkan kerangka konseptual pada Gambar 1.

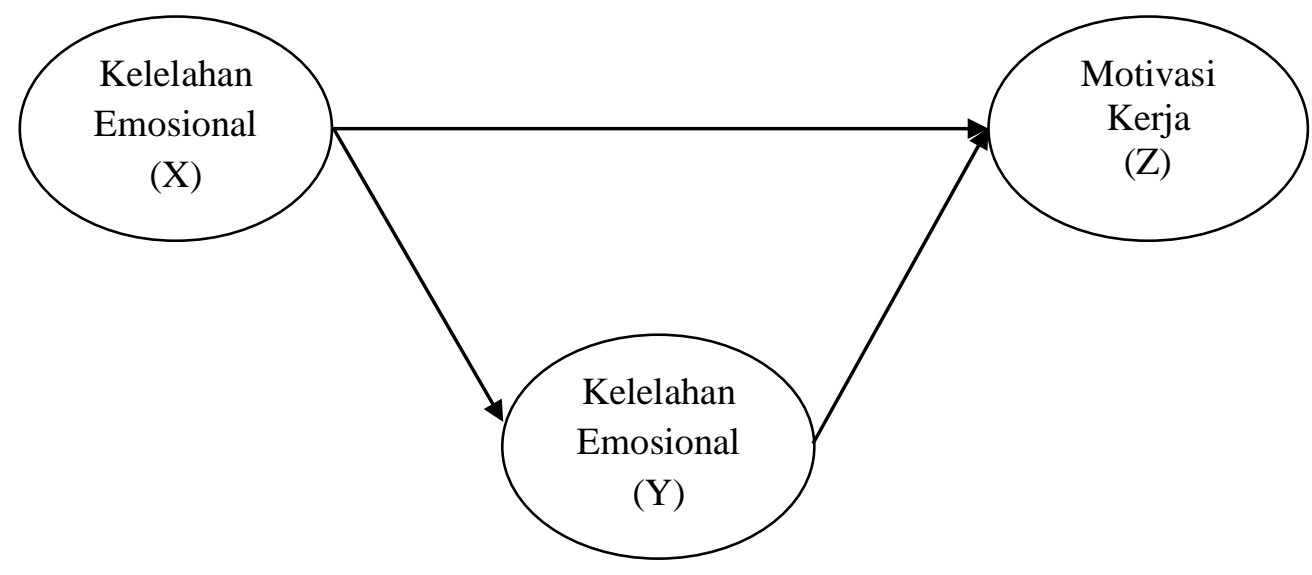

Gambar 1. Kerangka Konseptual Penelitian

Dari uraian di atas, hipotesis yang akan diuji dalam penelitian ini adalah :

1. Kelelahan emosional berpengaruh negatif dan signifikan terhadap motivasi kerja pegawai PT PLN (Persero) Cabang Ambon.

2. Kelelahan emosional berpengaruh negatif dan signifikan terhadap kepuasan kerja pegawai PT PLN (Persero) Cabang Ambon.

3. Motivasi kerja berpengaruh positif dan signifikan terhadap motivasi kerja pegawai PT PLN (Persero) Cabang Ambon. 


\section{METODE PENELITIAN}

Penelitian ini termasuk dalam jenis penelitian explanatory yang menjelaskan hubungan kausal dan pengujian hipotesa. Penelitian ini dilakukan di PT PLN (Persero) Wilayah Maluku dan Maluku Utara di Kota Ambon selama bulan bulan Juli- Agustus 2017. Data primer diperoleh dari daftar pertanyaan yang diberikan secara tertulis kepada para pegawai, sementara data sekunder diperoleh melalui literatur, jurnal ilmiah, majalah maupun data dokumen yang diperlukan untuk penelitian ini. Populasi penelitian adalah seluruh pegawai PT PLN (Persero) Wilayah Maluku dan Maluku Utara sebanyak 111 orang. Pengambilan sampel dilakukan dengan teknik simple random sampling sebanyak 52 orang dengan menggunakan formula yang disarankan oleh Yamane dan Slovin (1982) dalam Umar (2000). Sampel mewakili seluruh bagian yang ada dalam struktur organisasi, yang ditentukan dengan teknik proportionate stratified random sampling. Pengumpulan data menggunakan daftar pertanyaan tertutup, untuk mendapatkan data tentang dimensi-dimensi dari kelelahan emosional, motivasi kerja dan kepuasan kerja. Pernyataan dalam kuesioner dibuat menggunakan skala 1 (Sangat Tidak Setuju) - 5 (Sangat Setuju). Teknik analisis yang digunakan dalam penelitian ini adalah analisa deskriptif dan analisa jalur. Analisis deskriptif dalam bentuk tabulasi frekuensi untuk mendapatkan gambaran tentang tanggapan responden atas pernyataan yang diajukan dalam kuesioner. analisa jalur dimaksudkan untuk mengidentifikasi pengaruh variabel bebeas terhadap variabel terikat, secara langsung dan tidak langsung.

\section{PEMBAHASAN}

Karakteristik Responden

Responden penelitian ini berjumlah 52 orang pegawai PT PLN (Persero) Wilayah Maluku dan Maluku Utara. Hasil tabulasi menunjukan mereka terdiri dari 37 orang $(71,15 \%)$ laki-laki dan 15 orang $(28,85 \%)$ perempuan. Selanjutnya responden penelitian ini sebagian besar memiliki tingkat pendidikan sarjana sebanyak 24 orang $(46,15 \%)$, diploma sebanyak 16 orang $(30,77 \%)$, pascasarjana sebanyak 5 orang $(9,26 \%)$, dan SMA/sederajat sebanyak 7 orang $(13,46 \%)$. Dari masa kerja, responden penelitian ini yang telah bekerja antara 1-5 tahun sebanyak 7 orang $(13,46 \%)$, antara $6-10$ tahun sebanyak 26 orang $(50,00 \%)$, serta di atas 10 tahun sebanyak 19 orang (36,54\%). Sementara itu, responden penelitian ini yang belum kawin sebanyak 10 orang $(19,23 \%)$, kawin sebanyak 39 orang $(75,00 \%)$, dan selebihnya adalah mereka yang berstatus sebagai janda/duda sebanyak 3 orang $(5,77 \%)$.

\section{Hasil Penelitian}

Analisis deskriptif dilakukan untuk mendapatkan gambaran tentang respon yang diberikan responden terhadap pernyataan yang diajukan terkait dengan variabel yang diteliti. Hasil analisis deskriptif variabel kelelahan emosional $(X)$ menunjukan nilai rata-rata variabel kelelahan emosional 3,32 
yang diinterpretasikan cukup. Artinya rata-rata pegawai PT PLN (Persero) Wilayah Maluku dan Maluku Utara mengalami kelelahan secara emosional yang cukup memengaruhi mereka dalam pelaksanaan tugas pekerjaannya. Kelelahan emosional yang dialami diindikasikan melalui situasi pekerjaan yang cukup menimbulkan kesedihan, dan tekanan yang dialami dalam bekerja. Selain itu juga ditandai dengan adanya perasaan tidak mampu untuk bersaing dengan rekan kerja secara baik dan sehat. Akibatnya mereka sering berusaha menghindari untuk melaksanakan tugas pekerjaan dengan cara tidak masuk kantor. Bahkan ada keinginan dalam diri mereka untuk pindah ke tempat pekerjaan yang lain.

Sementara nilai rata-rata variabel motivasi kerja 3,44 diinterpretasikan baik atau bagus. Artinya sebagian besar karyawan PT PLN (Persero) Wilayah Maluku dan Maluku Utara memiliki motivasi kerja yang baik atau bagus. Motivasi kerja karyawan meliputi eksistensi, keterhubungan dan pertumbuhan. Keberadaan atau eksistensi setiap karyawan dipenuhi melalui bekerja untuk mewujudkan atau memuaskan kebutuhan dasar. Kebutuhan akan keterhubungan dengan pihak lain dipenuhi melalui hubungan kerja dengan sesama rekan kerja, penerimaan dan penghargaan yang diberikan oleh rekan kerja dan keterlibatan dalam aktivitas kerja kelompok. Kebutuhan untuk pertumbuhan dipenuhi melalui pencapaian prestasi dalam bekerja, dan pengakuan yang diberikan oleh rekan kerja dan atasan atas prestasi yang dicapai.

Selanjutnya nilai rata-rata variabel kepuasan kerja diinterpretasikan cukup. Artinya sebagian besar pegawai PT PLN (Persero) Wilayah Maluku dan Maluku Utara cukup merasakan adanya kepuasan dalam bekerja. Kepuasan kerja karyawan dipengaruhi oleh faktor pekerjaan itu sendiri, pengawasan dari atasan, rekan kerja, bayaran atau kompensasi, serta kesempatan promosi.

Analisis jalur digunakan untuk mengukur besarnya kontribusi atau pengaruh variabel bebas terhadap variabel terikat baik secara langsung maupun tidak langsung. Ringkasan hasil pengujian disajikan dalam tabel berikut.

Tabel 1 Coefficients Persamaan Sub Struktur 1

\begin{tabular}{|c|c|c|c|c|c|}
\hline \multirow[t]{2}{*}{ Model } & \multicolumn{2}{|c|}{$\begin{array}{l}\text { Unstandardized } \\
\text { Coefficients }\end{array}$} & \multirow{2}{*}{$\begin{array}{c}\text { Standardized } \\
\text { Coefficients } \\
\text { Beta }\end{array}$} & \multirow[t]{2}{*}{$\mathrm{t}$} & \multirow[t]{2}{*}{ Sig. } \\
\hline & $\mathrm{B}$ & Std. Error & & & \\
\hline (Constant) & 2,623 & 458 & & 5,723 & ,000 \\
\hline 1 Keletihan &,- 189 & 138 & -172 & 3,376 & ,001 \\
\hline
\end{tabular}

Emosional

a. Dependent Variable: Motivasi Kerja

Sumber : Hasil Pengolahan, 2017

Dari data dalam tabel 1 diketahui besarnya nilai konstanta 2,623 menunjukan apabila tidak ada pengaruh variabel Kelelahan Emosional maka nilai variabel Motivasi Kerja adalah 2,623 atau 262,3 \%. Selanjutnya nilai koefisien Kelelahan Emosional -0,172 yang menunjukan besarnya pengaruh 
negatif Kelelahan Emosional terhadap Motivasi Kerja pegawai PT PLN (Persero) Wilayah Maluku dan Maluku Utara adalah -0,172 atau -17,2 \%.

Berdasarkan hasil pengujian pada tabel 1 di atas, nilai t-hitung variabel Kelelahan Emosional adalah 3,376 dengan taraf signifikansi 0,001. Nilai t-tabel dengan $\alpha=0,05$ sebesar 2,68 sehingga nilai t-hitung $>$ t-tabel. Karena itu H0 ditolak dan $\mathrm{Ha}$ diterima, artinya terdapat pengaruh negatif Kelelahan Emosional (X) terhadap Motivasi Kerja (Y) pegawai PT PLN (Persero) Wilayah Maluku dan Maluku Utara. Hal ini diperkuat dengan nilai signifikansi kelelahan emosional sebesar $0,001<a(0,05)$. Dengan demikian pengaruh Kelelahan Emosional terhadap Motivasi Kerja sebesar -0,189 atau -18,9 \% adalah signifikan, sehingga hipotesis 1 yang diajukan diterima, di mana Kelelahan Emosional berpengaruh negatif dan signifikan terhadap Motivasi Kerja pegawai PT PLN (Persero) Wilayah Maluku dan Maluku Utara.

Ringkasan hasil pengujian persamaan sub struktur 1 disajikan dalam tabel 2 berikut.

Tabel 2. Model Summary Persamaan Sub Struktur 1

\begin{tabular}{llrrr}
\hline Model & $\mathrm{R}$ & $\mathrm{R}$ Square & Adjusted R Square & Std. Error of the Estimate \\
\hline 1 &, $871^{\mathrm{a}}$ &, 759 &, 759 &, 16312 \\
\hline
\end{tabular}

a. Predictors: (Constant), Kelelahan Emosional

Sumber : Hasil Pengolahan, 2017

Dari hasil tersebut, dapat dijelaskan pengaruh Kelelahan emosional (X) terhadap Motivasi Kerja (Y) sebesar 0,759 atau 75,9 \% sedangkan selebihnya 24,1 \% dipengaruhi oleh variabel lain yang tidak diikutkan dalam model. Dengan kata lain, variabilitas Motivasi Kerja dapat diterangkan menggunakan Kelelahan Emosional sebesar 75,9 \% sedangkan pengaruh selebihnya sebesar $24,1 \%$ oleh variabel-variabel lain yang tidak diikutkan dalam model ini.

Ringkasan hasil pengujian persamaan sub struktur 2 disajikan dalam tabel 3 berikut.

Tabel 3. Model Summary Persamaan Sub Struktur 2

\begin{tabular}{llrrr}
\hline Model & $\mathrm{R}$ & $\mathrm{R}$ Square & Adjusted R Square & Std. Error of the Estimate \\
\hline 1 &, $742^{\mathrm{a}}$ &, 551 &, 559 &, 124361 \\
\hline
\end{tabular}

a. Predictors: (Constant), Kelelahan Emosional, Motivasi Kerja

Sumber : Hasil Pengolahan, 2017

Dari hasil tersebut, dapat dijelaskan besarnya pengaruh variabel Kelelahan emosional (X) dan Motivasi Kerja (Y1) secara gabungan terhadap Kepuasan Kerja (Z) adalah 0,551 atau 55,1 \%. Hal ini berarti pengaruh Kelelahan emosional (X) dan Motivasi Kerja (Y) secara gabungan terhadap Kepuasan Kerja (Z) pegawai PT PLN (Persero) Wilayah Maluku dan Maluku Utara sebesar 55,1\%, sedangkan selebihnya 44,9\% dipengaruhi oleh faktor lain yang tidak diteliti. Dengan kata lain, variabilitas Kepuasan Kerja (Z) dapat diterangkan menggunakan variabel Kelelahan emosional $(X)$, dan motivasi kerja (Y) sebesar 55,1 \%, sedangkan pengaruh sebesar 44,9\% disebabkan oleh variabel-variabel lain di luar model penelitian ini. 
Pengujian hipotesis 2 dan 3 dilakukan dengan uji t. Secara parsial besarnya pengaruh Kelelahan Emosional (X), dan Motivasi Kerja (Y) terhadap Kepuasan Kerja (Z) dapat dilihat pada tabel berikut.

Tabel 4 Coefficients Persamaan Sub Struktur 2

\begin{tabular}{llrrrrr}
\hline Model & \multicolumn{2}{c}{$\begin{array}{c}\text { Unstandardized } \\
\text { Coefficients }\end{array}$} & $\begin{array}{c}\text { Standardized } \\
\text { Coefficients } \\
\text { Beta }\end{array}$ & t & Sig. \\
& B & Std. Error & & \\
\hline (Constant) & 3,070 &, 625 & & & 4,916 &, 000 \\
Kelelahan &,- 137 &, 154 &,- 114 & 2,892 &, 003 \\
Emosional & & & & & & \\
& Motivasi Kerja &, 149 &, 140 &, 137 & 3,065 &, 000 \\
\hline
\end{tabular}

a. Dependent Variable: Kepuasan Kerja

Sumber : Hasil pengolahan, 2017

Data hasil perhitungan dalam tabel 4, nilai konstanta 3,070 menunjukan apabila tidak ada pengaruh variabel Kelelahan Emosional, dan Motivasi Kerja maka besarnya nilai koefisien variabel Kepuasan Kerja pegawai PT PLN (Persero) Wilayah Maluku dan Maluku Utara adalah 3,070 atau 307,0 \%.

Selanjutnya nilai koefisien Kelelahan Emosional sebesar -0,114 menunjukan pengaruh Kelelahan Emosional terhadap Kepuasan Kerja pegawai PT PLN (Persero) Wilayah Maluku dan Maluku Utara sebesar -0,114 atau -11,4 $\%$. Nilai koefisien Motivasi Kerja sebesar 0,137 menunjukan pengaruh Motivasi Kerja terhadap Kepuasan Kerja pegawai PT PLN (Persero) Wilayah Maluku dan Maluku Utara sebesar 0,137 atau 13,7 \%.

Berdasarkan data hasil perhitungan dalam tabel 4, untuk melihat apakah pengaruh Kelelahan emosional (X) terhadap Kepuasan Kerja (Z) signifikan atau tidak, dilakukan pengujian hipotesis 2 dan 3. Nilai t-hitung Kelelahan emosional adalah 2,892 dengan signifikansi 0,003. Besarnya nilai t-tabel adalah 2,68 sehingga nilai t-hitung $>$ t-tabel maka H0 ditolak dan Ha diterima, artinya terdapat pengaruh negatif variabel Kelelahan Emosional (X) terhadap Kepuasan Kerja (Z) pegawai PT PLN (Persero) Wilayah Maluku dan Maluku Utara. Hal ini juga diperkuat dengan nilai signifikansi Kelelahan Emosional sebesar 0,003 < a $(0,05)$. Dengan demikian, pengaruh Kelelahan Emosional 0,114 atau $-11,4 \%$ dianggap signifikan sehingga hipotesa kedua yang diajukan dalam penelitian ini dapat diterima, di mana Kelelahan Emosional berpengaruh negatif dan signifikan terhadap Kepuasan Kerja pegawai PT PLN (Persero) Wilayah Maluku dan Maluku Utara.

Selanjutnya hasil pengujian menunjukan nilai t-hitung Motivasi Kerja adalah 3,065 dengan signifikansi 0,000. Karena nilai t-hitung > t-tabel, H0 ditolak dan $\mathrm{Ha}$ diterima, artinya terdapat pengaruh positif yang signifikan Motivasi Kerja (Y) terhadap Kepuasan Kerja (Z) pegawai PT PLN (Persero) Wilayah Maluku dan Maluku Utara. Hal ini juga diperkuat dengan nilai signifikansi Motivasi Kerja sebesar 0,000 < a $(0,05)$. Dengan demikian pengaruh variabel Motivasi Kerja terhadap Kepuasan Kerja sebesar 0,137 atau 13,7 \% dianggap signifikan sehingga hipotesa ketiga yang diajukan dalam penelitian 
ini dapat diterima, di mana Motivasi Kerja berpengaruh positif dan signifikan terhadap Kepuasan Kerja (Z) pegawai PT PLN (Persero) Wilayah Maluku dan Maluku Utara.

Secara ringkas, hasil pengujian menggunakan analisis jalur atas pengaruh variabel kelelahan emosional terhadap motivasi kerja dan kepuasan kerja pegawai PT PLN (Persero) Wilayah Maluku dan Maluku Utara dapat diringkas dalam tabel berikut.

Tabel 5. Hasil Perhitungan Pengaruh Antar Variabel

\begin{tabular}{llcc}
\hline \multicolumn{1}{c}{ Pengaruh } & \multicolumn{1}{c}{ Variabel } & Motivasi Kerja & Kepuasan Kerja \\
\hline Langsung & Kelelahan & $-0,172$ & $-0,114$ \\
& Emosional & & \\
\multirow{2}{*}{ Tidak Langsung } & Motivasi Kerja & - & 0,137 \\
\multirow{2}{*}{ Total } & Kelelahan & - & $-0,02356$ \\
& Emosional & & \\
& Kelelahan & - & $-0,035$ \\
\hline
\end{tabular}

Sumber : Hasil perhitungan, 2017

\section{Pembahasan}

Hasil deskriptif variabel kelelahan emosional menunjukan rata-rata pegawai PT PLN (Persero) Wilayah Maluku dan Maluku Utara mengalami kelelahan secara emosional yang cukup memengaruhi mereka dalam pelaksanaan tugas pekerjaan yang dipercayakan bagi mereka. Kelelahan emosional yang dialami diindikasikan melalui situasi pekerjaan yang cukup menimbulkan kesedihan, dan tekanan yang dialami dalam bekerja. Selanjutnya kelelahan emosional yang dialami juga ditandai dengan adanya perasaan tidak mampu untuk bersaing dengan rekan kerja secara baik dan sehat. Akibatnya mereka sering berusaha menghindari untuk melaksanakan tugas pekerjaan dengan cara tidak masuk kantor. Bahkan ada keinginan dalam diri mereka untuk pindah ke tempat pekerjaan yang lain.

Secara deskriptif sebagian besar pegawai PT PLN (Persero) Wilayah Maluku dan Maluku Utara memiliki motivasi kerja yang baik. Motivasi kerja karyawan meliputi eksistensi, keterhubungan dan pertumbuhan. Keberadaan atau eksistensi setiap karyawan dipenuhi melalui bekerja untuk mewujudkan atau memuaskan kebutuhan dasar. Kebutuhan akan keterhubungan dengan pihak lain dipenuhi melalui hubungan kerja dengan sesama rekan kerja, penerimaan dan penghargaan yang diberikan rekan kerja dan keterlibatan dalam aktivitas kerja kelompok. Kebutuhan untuk pertumbuhan dipenuhi antara lain melalui pencapaian prestasi dalam bekerja, dan pengakuan yang diberikan oleh rekan kerja dan atasan atas prestasi yang dicapai.

Demikian pula nilai rata-rata variabel kepuasan kerja diinterpretasikan cukup. Artinya sebagian besar pegawai PT PLN (Persero) Wilayah Maluku dan Maluku Utara cukup merasakan adanya kepuasan dalam bekerja. Kepuasan 
kerja karyawan dipengaruhi oleh faktor pekerjaan itu sendiri, pengawasan dari atasan, rekan kerja, bayaran atau kompensasi, serta kesempatan promosi.

Kelelahan emosional yang dialami oleh pegawai PT PLN (Persero) Wilayah Maluku dan Maluku Utara, antara lain disebabkan oleh adanya tekanan dari beban pekerjaan serta kondisi lingkungan tempat bekerja. Beban pekerjaan yang dialami oleh para pegawai seringkali membuat mereka merasa sedih dan tertekan, sehingga kadangkala merasa tidak tidak mampu untuk bersaing dengan rekan kerja secara sehat. Kondisi ini menunjukan sebagian besar pegawai PT PLN (Persero) Wilayah Maluku dan Maluku Utara mengalami kelelahan secara emosional dalam bekerja. Karena itu, menjadi tugas dari manajemen perusahaan untuk senantiasa berupaya mengurangi tingkat kelelahan emosional yang dialami oleh para pegawai, antara lain melalui program refreshing bersama. Selain itu, perlu pula dilakukan perbaikan atas situasi dan kondisi pekerjaan di lingkungan PT PLN (Persero) Wilayah Maluku dan Maluku Utara. Suasana kerja yang menggembirakan dapat diciptakan, misalnya pada waktu pagi ada pemutaran musik intrumentalia ringan, atau pada sore hari beberapa sebelum selesai jam kerja.

Dari hasil pengujian secara statistik, terdapat pengaruh negatif variabel Kelelahan Emosional (X) terhadap Motivasi Kerja (Y1) pegawai PT PLN (Persero) Wilayah Maluku dan Maluku Utara. Dengan demikian, pengaruh variabel Kelelahan Emosional terhadap Motivasi Kerja adalah signifikan, di mana Kelelahan Emosional berpengaruh secara negatif dan signifikan terhadap Motivasi Kerja dan Kepuasan Kerja pegawai PT PLN (Persero) Wilayah Maluku dan Maluku Utara. Sementara Motivasi kerja berpengaru positif dan signifikan terhadap Kepuasan Kerja. Hasil penelitian ini sejalan dan mendukung hasil penelitian sebelumnya yang dilakukan oleh Tawale, dkk., (2011) dan Koltunovych (2013), Low et al. (2001), Zagladi (2004), Al-Khatani dan Allam (2014) serta Syech, et al. (2015), Gibson et al. (1996), Igalens dan Roussel (1999), serta Jehanzeb et al. (2012) .

\section{PENUTUP}

\section{Kesimpulan}

Berdasarkan hasil penelitian dan pembahasan, dengan menggunakan analisis regresi sederhana dapat diketahui pengaruh dari variabel kelelahan emosional (X) terhadap motivasi kerja (Y1 pegawai PT PLN (Persero) Wilayah Maluku dan Maluku Utara. Karena itu kesimpulan yang dapat diambil dari hasil penelitian ini adalah variabel Kelelahan Emosional berpengaruh secara negatif dan signifikan terhadap Motivasi Kerja pegawai PT PLN (Persero) Wilayah Maluku dan Maluku Utara. Hasil ini menunjukan kelelahan emosional yang dialami dapat menurunkan motivasi kerja pegawai PT PLN (Persero) Wilayah Maluku dan Maluku Utara. Oleh karena itu, menjadi tugas pihak manajemen PT PLN (Persero) Wilayah Maluku dan Maluku Utara untuk berupaya mengurangi bahkan menghilangkan faktor-faktor yang menjadi 
penyebab terjadinya kelelahan emosional dari para pegawainya sehingga motivasi kerja mereka menjadi terjaga, bahkan dapat ditingkatkan.

\section{Implikasi Penelitian}

Berdasarkan pembahasan sebelumnya, dapat diberikan saran-saran baik untuk pengembangan ilmu pengetahuan maupun untuk kepentingan praktis, antara lain :

1. Karena variabel Kelelahan Emosional terbukti memiliki pengaruh yang negatif terhadap Motivasi Kerj dan Kepuasan Kerja pegawai, pihak manajemen PT PLN (Persero) Wilayah Maluku dan Maluku Utara hendaknya senantiasa berupaya untuk mengurangi kelelahan emosional yang dialami para pegawai melalui upaya-upaya mengatasi faktor-faktor fisik, emosi dan mental yang menjadi penyebab munculnya kelelahan emosional. Baik itu faktor yang bersumber dari diri individu pegawai, lingkungan kerja maupun dalam hubungan dengan pelanggan.

2. Untuk meningkatkan motivasi bekerja dalam diri para pegawai, diharapkan manajemen perusahaan dapat pula menyelenggarakan pelatihan dan pengembangan motivasi diri pegawai secara berkala. Selain itu, upaya yang dapat dilakukan antara lain membina kerjasama dan kekompakan dalam kelompok pegawai yang dilakukan melalui pelatihan outbound serta pemberian penghargaan atas prestasi kerja yang dicapai oleh pegawai, yang dikaitkan dengan ulang tahun perusahaan, dan sejenisnya.

\section{DAFTAR PUSTAKA}

Al-Kahtani, Nasser S. and Zafrul Allam, 2014. The influence of job burnout, involvement and locus of control on job satisfaction: Some explorations from banking sector in Saudi Arabia, New York Science Journal, 2014;7(2)

Amelia, R., dan Zulkarnain. 2005. Konsep Diri dan Tingkat Burnout Pada Pegawai yang Bekerja di Instansi Pelayanan Masyarakat. Psikologika. No.19 Tahun X.

Anoraga P. 1992. Psikologi Kerja. Jakarta : Rineka Cipta

As'ad, Moh. 1995. Psikologi Industri. Seri Ilmu Sumber Daya Manusia. Jakarta: Liberty.

Cherniss, Cary. 1980. Professional Burnout in Human Service Organizations. New York: Praeger Publishers

Farber, Barry A., Crisis In Education: Stress and Burnout in the American Teacher, San Francisco: Jossey-Bass Publishers

Gibson, J.L, Ivancevich, and Donelly, J.H., Jr., 1996. Organization Behavior : Structure, Process, Diterjemahkan oleh Djarkasih, Jakara:Erlangga

Greenberg, Jerald dan A. Baron. 1993. Behavior in Organization, Understanding and Managing the Human side of Work, edisi kelima, New Jersey: Prentice Hall inc., Englewood Cliff 
Igalens, Jacques Igalens and Roussel , Patrice, 1999. A Study of the Relationships between Compensation Package, Work Motivation and Job Satisfaction, Journal of Organizational Behavior, Vol. 20, No. 7 (Dec., 1999), 1003-1025

Jehanzeb, Khawaja, Mazen F. Rasheed, Anwar Rasheed and Alamzeb Aamir, 2012. Impact of Rewards and Motivation on Job Satisfaction in Banking Sector of Saudi Arabia, International Journal of Business and Social Science, Vol. 3 No. 21; November

Kartono, Kartini. 1994. Psikologi Sosial untuk Manajemen, Perusahaan dan Industri, Jakarta: Raja Grafindo Persada.

Koltunovych, Tetiana. 2013. The Peculiarities of Motivational Sphere of Preschool Teachers with Different Levels of Professional Burnout, Proceedings of the 11th edition of the International Conference on Sciences of Education, June

Low, G. S., Cravens, D. W., Grant, K., and Moncrief, W.C., 2001. Antecedents and consequences of salesperson burnout, European Journal of Marketing, 35, 587-614.

Luthans, F. 2006. Organizational Behavior. 8th edition. New York: The McGrawHill Co., Inc.

Mangkunegara, A.P. 2001. Psikologi Perusahaan. Bandung:Tri Genda Karya. 2001. Manajemen Sumber Daya Manusia Perusahaan. Bandung : Remaja Rosdakarya

Manullang, M. 2002. Managemen Personalia. Jakarta:Ghalia Indonesia.

Maslach, C., 1986. Stress, burnout, and the workaholic syndrome. In R. Kilburg, R. Thoreson, and P. Nathan (Eds.), Professionals in distress: Issues, syndromes and solutions in psychology (53-75). Washington, DC: American Psychological Association.

Maslach, C., and Jackson, E. 1986. Maslach Burnout Inventory Manual, Palo Alto: Consulting Psychologists Press.

Maslach, C., 1993. Burnout: A multidimensional perspective. In W. B. Schaufeli, C. Maslach, \& T. Marek (Eds.), Professional burnout: Recent developments in theory and research (19-32). Washington, DC: Taylor \& Francis.

Motowidlo, Stephan J. and Arthur P. Brief. 1986. Prosocial Organizational Behaviors, The Academy of Management Review Vol. 11, No. 4 (Oct), 710-725

Piko, B.F. 2006. Burnout, Role Conflict, Job Satisfaction and Psychosocial Health Among Hungarian Health Care Staff: A Questionnaire Survey, International Journal of Nursing Studies, Vol. 43, 311-318

Pines, Ayala and Aronson, Elliot, 1989. Career Burnout: Causes and Cures, New York: The Free Press, A Division of Macmillan, Inc

Prosser D, Johnson S, Kuipers E, Dunn G, Szmukler G, Reid Y, et al. 1999. Mental health, "burnout" and job satisfaction in a longitudinal study of mental health staff, Social Psychiatry Epidemiology, 295- 300.

Reksohadiprojo, Sukanto, dan T. Hani Handoko, 1999. Organisasi Perusahaan: Teori, Struktur dan Perilaku. Yogyakarta:BPFE 
Robbins S. P. 1996. Perilaku Organisasi. Terjemahan Diana Angelica.Jakarta: Salemba Empat.

Schaufeli, W.B., and Buunk, B.P. 1996. Professional Burnout. Handbook of Work and Health Psychology, Schabracq, M.J., Winnubst, J.A.M., Cooper, C.L.(editor). Chichester: John Wiley and Sons Ltd.

Siagian, Sondang P. 2002. Manajemen Sumber Daya Manusia. Penerbit Bumi Aksara. Jakarta.

Simamora, Henry. 2007. Manajemen Sumber Daya Manusia, Yogyakarta: YKPN

Stanley S.M, Whitton S.W, Markman HJ. 2004. Maybe I do: Interpersonal commitment and premarital or nonmarital cohabitation, Journal of Family Issues, 25 (4), 496-519.

Suprihanto, John, et al. 2003, Perilaku Organisasi, Yogyakarta: Sekolah Tinggi Ilmu Ekonomi YKPN

Syech, Idrus, Alhabji Taher, M. Al Musadieq, dan Utami Hamidah Nayati, 2015, The Effect of Psychological Empowerment on Self-Efficacy, Burnout, Emotional Intelligence, Job Satisfaction, and Individual Performance (An Empirical Study on Tour Guides in West Nusa Tenggara), European Journal of Business and Management, Vol.7, No.8, 2015, 139-149

Tawale, Efa Novita, Widjajaning Budi, Gartinia. 2011. Hubungan antara Motivasi Kerja Perawat dengan Kecenderungan mengalami Burnout pada perawat, di RSUD Serui-Papua, INSAN Vol. 13 No. 02, Agustus

Umar, Husein. 2000. Metode Penelitian. Edisi Pertama, Jakarta : Raja Grafindo Persada

Zagladi, 2004. Pengaruh Kelelahan Emosional Terhadap Kepuasan Kerja dan Kinerja Dalam Pencapaian Komitmen Organisasional Dosen Perguruan Tinggi Swasta. Jurnal Penelitian., Program Pasca Sarjana Universitas Brawijaya. Vol. VII No. 1, 79-84 